\title{
Haemolytic episode in G6 PD deficient workers exposed to TNT
}

\author{
L. S. DJERASSI and L. VITANY \\ Department of Occupational Health, Workers' Sick Fund, 35 Rothshild Avenue, Haifa, Israel
}

\begin{abstract}
Djerassi, L. S. and Vitany, L. (1975). British Journal of Industrial Medicine, 32, 54-58. Haemolytic episode in G6 PD deficient workers exposed to TNT. This is a report on three cases of acute haemolytic disease in glucose-6-phosphate dehydrogenase (G6 PD) deficient workers exposed to trinitroluene (TNT). The courses of the haemolytic crises have several features in common, the most striking being the onset of the disease within two to four days after the start of exposure, and the fact that this has been the first and so far the only haemolytic episode in their lives in spite of detailed medical records of past diseases, injuries, and medications during 12 to 16 years preceding the haemolytic crisis and five to nine years following the disease.

The lowest haemoglobin levels for the three patients were $4 \cdot 0,6 \cdot 8$, and $8 \cdot 2 \mathrm{~g} / \mathrm{dl}$ respectively; haematocrit values were 17 and $24 \%$; reticulocytes rose in case 1 to $26.2 \%$, in case 2 to $26 \%$, and in case 3 to $10 \%$.

Indirect bilirubinaemia was increased in two patients $(5.1$ and $2.6 \mathrm{mg} / 100 \mathrm{ml})$ and stercobilinogen was as high as $2150 \mathrm{mg} / 24 \mathrm{hr}$ in one patient. The presence of the metabolite monoamino 2-6 dinitrotoluene was proved in the urine of case 3 and reached $21 \gamma \%$.

The possibility of a dose-response relationship is briefly discussed and the risk of exposing G6 PD individuals in chemical processes is mentioned.
\end{abstract}

The exposure of many thousands of workers to TNT, the most commonly used explosive since the first world war, has resulted in the extensive study of its toxicity (von Oettingen, 1941; Hamblin, 1962; Hassman and Jicha, 1967; Ermakov, Aizenshtadt, and Ventsenostev, 1969; Soboleva, 1969; Poljak and Pejuskovic, 1969; Vasilenko and Sonkin, 1969; Zakharova and Manoilova, 1971; Goodwin, 1972).

The major conditions hepatitis and aplastic anaemia have been responsible for several fatalities (von Oettingen, 1941; Hayhoe, 1953; Crawford, 1954; Moeschlin, 1964).

Less important are gastritis, dermatitis, and irritation of the mucous membranes, upper respiratory tract, and conjunctivae. In a few instances neurological disturbances (Sievers, 1947; Kaganov, Fediushina, and Botchenkova, 1970) and damage to the kidneys have been suspected (Djerassi, 1964;
Moeschlin, 1964), and recently attention has been drawn to the possibility of injury to the crystalline lens of the eye (Paterson, 1972).

The noxious effects of TNT on blood so far observed are the very hazardous impairment of erythropoiesis in the bone marrow, as already mentioned, and the increased formation of methaemoglobin. Minor degrees of cyanosis due to methaemoglobinaemia have been observed quite frequently (von Oettingen, 1941; Roberts, 1941; Crawford, 1954; Hunter, 1969) and Jope (1946) reported one case of sulphaemoglobin formation.

There is however little evidence of a clearcut haemolytic crisis as a presenting syndrome of TNT poisoning. Stewart, Witts, Higgins, and O'Brien (1945) observed some degree of haemolysis in students who had volunteered to fill shells with TNT during their vacation. In their search for haemolytic 
episodes in G6 PD deficient industrial workers Szeinberg et al. (1959) cite a $2.7 \%$ reticulocytosis in an otherwise healthy TNT exposed individual suffering from G6 PD deficiency.

Dror's (1959) short description of a recurrent anaemia in TNT poisoning arouses suspicion of some degree of haemolysis; the investigations performed however are not conclusive.

Thus we thought it pertinent to report on three cases of haemolytic crisis in G6 PD deficient individuals who belong to a working population under our supervision during the last 14 years.

\section{Methods}

(a) The determination of glucose-6-phosphate-dehydrogenase (G6 PD) is based on the reduction of triphosphopyridine nucleotide (TPN) in the presence of G6 PD, using the rate of reaction assay at a wavelength of $340 \mu \mathrm{m}$, as suggested by Kornberg and Horecker (1955) and modified by Farrand (1961). The amount of reduced TPN is estimated after exactly one minute using a Beckman spectrophotometer. The normal values of this type of rate of reaction assay are 20-30 units per minute, according to Farrand.

\section{Reagents}

Glycyl glycine buffer pH-7.4, 0.25 mol/1 (3.3 gr/100)

Magnesium sulphate $0 \cdot 1 \mathrm{~mol} / \mathrm{l}\left(2 \cdot 465 \mathrm{~g} \mathrm{MgSO}_{4} \cdot 7 \mathrm{H}_{2} \mathrm{O} / 100\right)$

TPN 0.001 mol/1 (mol.wt 743, Na salt mol.wt 765.4) 3.82 $\mathrm{mg}$ TPN $/ 5 \mathrm{ml} \mathrm{H}_{2} \mathrm{O}$

Glucose-6-phosphate $\quad 0 \cdot 1 \quad \mathrm{~mol} / \mathrm{l} \quad(\mathrm{mol} / \mathrm{wt} \quad 260 \cdot 1 \quad \mathrm{Ba}$ salt. $7 \mathrm{H}_{2} \mathrm{O}$ mol.wt $526 \cdot 6$, disodium salt mol.wt $304 \cdot 1$ ) $30 \cdot 4 \mathrm{mg} \mathrm{G} 6 \mathrm{P} / 1 \mathrm{ml} \mathrm{H}_{2} \mathrm{O}$.

\section{Method}

$\begin{array}{lcl} & \begin{array}{c}\text { Blank } \\ (\mathrm{ml})\end{array} & \begin{array}{l}\text { Test } \\ (\mathrm{ml})\end{array} \\ \text { Glycylglycine buffer } & 0 \cdot 2 & 0 \cdot 2 \\ \text { Magnesium sulphate } 0 \cdot 1 \mathrm{~mol} / \mathrm{l} & 0 \cdot 2 & 0 \cdot 2 \\ \text { TPN } & - & 0 \cdot 15 \\ \text { Heparinized blood 1:15 in } \mathrm{H}_{2} \mathrm{O} & 0 \cdot 1 & 0 \cdot 1 \\ \text { Aqua dest. } & 0.5 & 0 \cdot 3 \\ \text { G-6-Phosphate } & - & 0.05\end{array}$

Reading at $340 \mu \mathrm{m}$ (sensitivity-4).

All reactions are performed on ice-cooled reagents and blood, always using a normal blood sample simultaneously.

(b) Stercobilinogen is determined according to a method suggested by Maclagan (1946), using a single specimen of faeces examined with Ehrlich's reagent. The normal range is $20-220 \mathrm{mg} / 100 \mathrm{~g}$ faeces and $20-280 \mathrm{mg}$ daily.

(c) 2-6 Nitrotoluene is estimated according to a method described by Snyder and von Oettingen (1943).

\section{Case histories}

The three cases to be presented have several common characteristics. They were on the same job filling shells with TNT mixture and all were G6 PD deficient. Two of them were born in Iraq, the third in Israel to Iraqi parents; there was no evidence of ingestion of fava beans or mushrooms; the workers had not taken any drugs or medication during at least the four weeks preceding the haemolytic episode (Table 1). Last but not least, the haemolytic crisis observed was the first haemolytic episode in their lives and up to then the only one from which they had suffered.

Case 1 M.I. (Table 2 and Figure)

An 18 year-old, unmarried obese boy, Israeli by birth, had a past history of impetigo, smallpox, abscess of the right forearm, bruised calf, traumatic fracture of right forearm, and pyrexia of unknown origin. Blood count and urine analysis performed routinely before the start of exposure to TNT were normal. He went on to the job of filling TNT on 12 May, felt unwell the following day but continued to work. On the third working day he felt so miserably weak that he sought medical advice. Weakness, vertigo, and some nausea were his chief complaints; at home he was told that he looked very pale.

Our examination revealed paleness, a slightly enlarged liver and spleen, fever $38^{\circ} \mathrm{C}$, pulse rate of 130 per minute, haemoglobin $10.6 \mathrm{~g} / \mathrm{dl}$, and reticulocytes $9.0 \%$. He was hospitalized immediately with the suspicion of an acute haemolytic crisis. His state continued to deteriorate, fever rose to $39.7^{\circ} \mathrm{C}$, hepatosplenomegaly increased, haemoglobin dropped to $4.0 \mathrm{~g} / \mathrm{dl}$; haematocrit was as low as 1.7 , reticulocytosis $26.2 \%$. At this point steroid treatment was given and eventually the course of the disease changed dramatically. The patient improved and recovered completely. His occupation with TNT was

TABLE 1

TIMING OF EVENTS

\begin{tabular}{|c|c|c|c|c|c|}
\hline & & & Case I & Case 2 & Case 3 \\
\hline $\begin{array}{l}\text { Age (yr). . } \\
\text { Start of exposure to TNT } \\
\text { Probable start of haemolytic } \\
\text { First examination } \\
\text { Days of exposure preceding } \\
\text { tic crisis } . \\
\text { Previous exposure to TNT } \\
\text { Days of exposure overall }\end{array}$ & $\begin{array}{l}\cdots \\
\text { crisis } \\
\text { haemol } \\
\ldots \\
\ldots \\
\ldots\end{array}$ & $\begin{array}{l}\cdots \\
\cdots \\
\cdots \\
\cdots \\
\cdots \\
\cdots \\
\cdots\end{array}$ & $\begin{array}{c}18 \\
12 \text { May } 1968 \\
14 \text { May } 1968 \\
15 \text { May } 1968 \\
2 \\
\text { None } \\
3\end{array}$ & $\begin{array}{c}23 \\
8 \text { May } 1968 \\
10 \text { May } 1968 \\
16 \text { May } 1968 \\
2-3 \\
\text { None } \\
4\end{array}$ & $\begin{array}{c}35 \\
31 \text { Aug. } 1963 \\
2 \text { Sept. } 1963 \\
5 \text { Sept. } 1963 \\
2 \\
15 \text { Jan.-30 May } 1963 \\
60+\end{array}$ \\
\hline
\end{tabular}


TABLE 2

CASE 1 Aged 18 Years

\begin{tabular}{|c|c|c|c|c|c|c|c|c|}
\hline & \multicolumn{7}{|c|}{1968} & \multirow{2}{*}{$\frac{1973}{17 \text { Sept }}$} \\
\hline & 25 Mar. & 15 May & 17 May & 18 May & 21 May & 26 May & 30 May & \\
\hline Haemoglobin (g/dl) & $14 \cdot 0$ & $10 \cdot 6$ & - & $4 \cdot 0$ & $6 \cdot 8$ & $9 \cdot 2$ & $11 \cdot 2$ & - \\
\hline Haematocrit (vol \%) & 44 & 35 & 一 & 17 & - & - & - & 一 \\
\hline Reticulocytes $(\% /$ rbc) & - & $9 \cdot 0$ & $19 \cdot 0$ & $26 \cdot 2$ & - & $4 \cdot 0$ & 一 & 0.8 \\
\hline \multicolumn{9}{|l|}{$\begin{array}{l}\text { Bilirubin indirect (normal } \\
\text { value less than } 1 \cdot 0\end{array}$} \\
\hline $\mathrm{mg} / 100 \mathrm{ml}$ ) & - & - & $5 \cdot 1$ & - & - & 一 & $0 \cdot 8$ & - \\
\hline $\begin{array}{l}\text { Coombs test } \\
\text { G6 PD (normal value } 10-20\end{array}$ & 一 & - & Negative & 一 & Negative, & 一 & - & 一 \\
\hline$\mu / \mathrm{g} \mathrm{Hb})^{*}$ & - & - & - & $1 \cdot 2$ & - & - & - & $3 \cdot 0$ \\
\hline Temperature ${ }^{\circ} \mathrm{C}$ & 一 & $38 \cdot 2$ & $37 \cdot 8$ & $39 \cdot 7$ & $37 \cdot 2$ & $36 \cdot 5$ & 一 & 一 \\
\hline
\end{tabular}

*Farrand's modification of method of Kornberg and Horecker (1955)

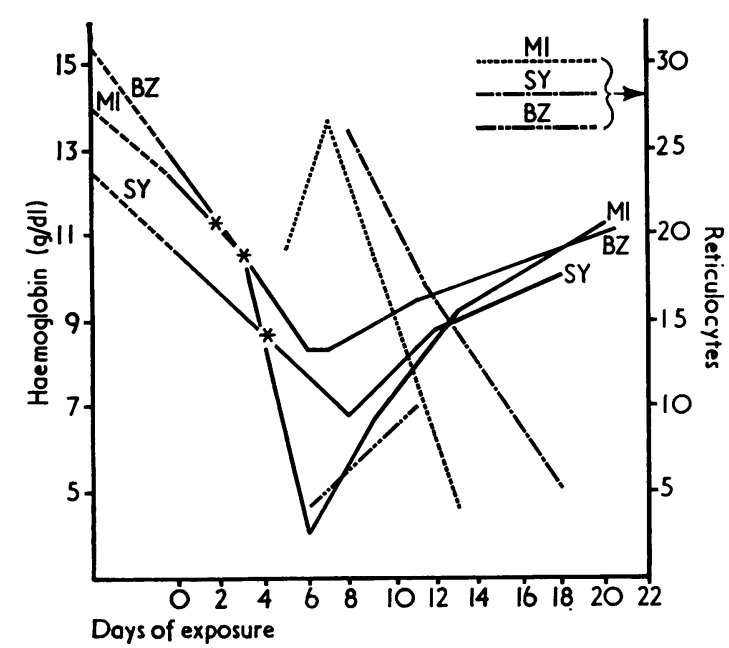

FIGURE Haemoglobin and reticulocytes during haemolytic crisis: * end of exposure. discontinued. Since then there have been no further complaints related to his G6 PD deficiency.

Case 2 S.Y. (Table 3 and Figure)

This 23-year-old married man, father of one child, emigrated to Israel 17 years before his haemolytic episode. The medical records in the Workers' Sick Fund revealed that he had suffered from typhoid fever, traumatic haemarthrosis of the right knee, fracture of the left forearm, and less important contusions of the lower limbs. Five weeks before exposure to TNT he had an haemoglobin of $12.5 \mathrm{~g} / \mathrm{dl}$ and a normal urine analysis. He started his job in shell filling on 8 May 1968. Weakness was his first and predominant complaint. Vertigo, headache, loss of appetite, and fever followed; his urine became dark and he was told that he looked rather pale. In spite of progressive discomfort he remained on his job for four days, stayed at home for a further three days, and came to see us when fever appeared. Paleness, a slightly enlarged spleen, a haemoglobin of $6.8 \mathrm{~g} / \mathrm{dl}$, reticulocytosis $26.0 \%$, and greatly increased urobilinogen in the urine made the diagnosis of an acute haemolytic crisis most probable. On hospitalization he recovered without specific treatment (Table 3 ). He dis-

TABLE 3

CASe 2 aged 23 Years

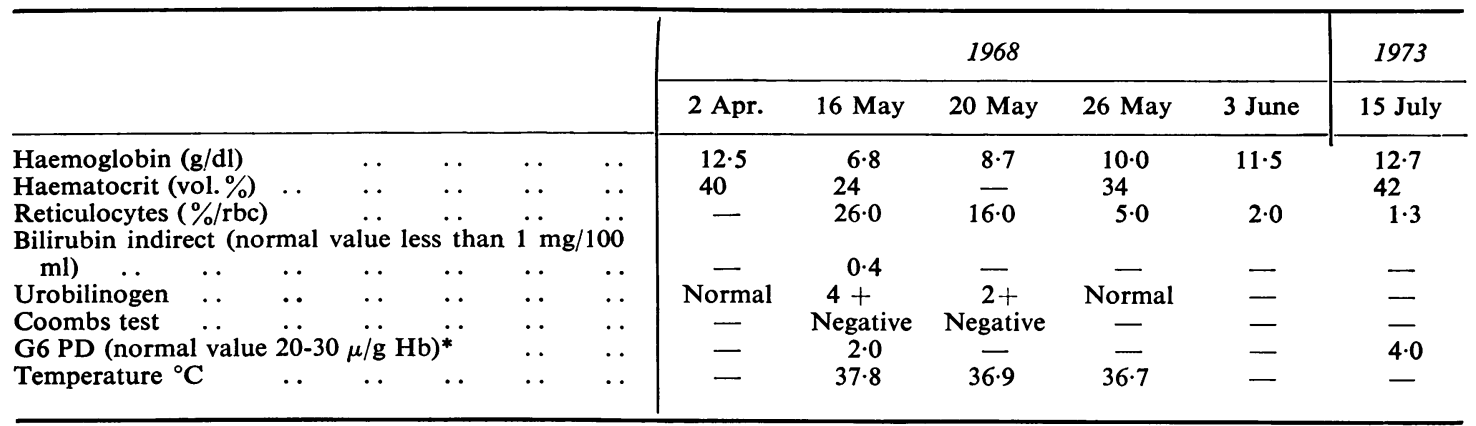

*Method of Kornberg and Horecker (1955) 
TABLE 4

CASE 3 aged 35 Years

\begin{tabular}{|c|c|c|c|c|c|c|c|c|c|}
\hline \multirow[t]{2}{*}{ - } & \multicolumn{8}{|c|}{1963} & \multirow{2}{*}{$\frac{1973}{15 \text { July }}$} \\
\hline & 5 Aug. & 5 Sept. & 6 Sept. & 10 Sept. & 12 Sept. & 19 Sept. & 3 Oct. & 28 Oct. & \\
\hline Haemoglobin $(\mathrm{g} / \mathrm{dl})$ & $15 \cdot 5$ & $8 \cdot 2$ & $8 \cdot 2$ & $9 \cdot 5$ & - & $11 \cdot 0$ & - & $13 \cdot 0$ & $13 \cdot 8$ \\
\hline Reticulocytes ( $\%$ rbc) & - & $4 \cdot 0$ & - & $10 \cdot 0$ & - & $3 \cdot 7$ & - & $2 \cdot 0$ & 0.8 \\
\hline \multirow{2}{*}{\multicolumn{10}{|c|}{ Bilirubin indirect (normal value }} \\
\hline & - & $2 \cdot 6$ & 一 & $1 \cdot 4$ & - & - & - & 0.6 & - \\
\hline Coombs test & - & - & - & Negative & Negative & - & - & - & - \\
\hline $\begin{array}{l}\text { 2-6 dinitro amino toluene in } \\
\text { urine } / 100 \mathrm{ml} \text { (normally none) }\end{array}$ & 一 & - & 21 & 16 & - & - & 一 & - & - \\
\hline G6 PD (normal value $20-30$ & & & & & & & & & \\
\hline$\mu / \mathrm{g} \mathrm{Hb}$ & 一 & 一 & $2 \cdot 0$ & $0 \cdot 8$ & - & - & - & - & 3.0 \\
\hline Temperature ${ }^{\circ} \mathrm{C}$ & 一 & $37 \cdot 8$ & $37 \cdot 0$ & $36 \cdot 8$ & 一 & 一 & 一 & 一 & - \\
\hline
\end{tabular}

continued his job and no further complaints relating to G6 PD deficiency have since been recorded.

Case 3 B.Z. (Table 4 and Figure)

A 35-year-old unskilled male worker, married and father of three children, emigrated from Iraq to Israel 13 years before his haemolytic episode. Examination of his medical records in the Sick Fund revealed that he had been repeatedly treated for low back pain, upper respiratory tract infections, bronchitis, corneal erosion; and a foreign body of the left eye. He was first employed on a TNT job for more than 60 days between January and May 1963 and no untoward effects were noticed. A routine blood count and urine analysis on 5 August 1963 proved to be within normal limits. His occupational exposure to TNT started again on 31 August 1963. Within two days he was afflicted by severe headache, vertigo, and progressive weakness. Abdominal pain, nausea, occasional vomiting, and dark urine followed. On 5 September a haemolytic syndrome was suspected with paleness, subicteric conjunctivae, slightly enlarged spleen and liver, haemoglobin $8 \cdot 2 \mathrm{~g} / \mathrm{dl}$. $2 \cdot 9$ million erythrocytes, $4.0 \%$ reticulocytes, and Jolly bodies and erythroblasts in peripheral blood smears. Indirect bilirubin $2.6 \mathrm{mg} / 100 \mathrm{ml}$; urobilinogen in the urine greatly increased. Sternal puncture showed a hyperplastic bone marrow with marked proliferation of erythroblasts, the ratio white cells: erythroblasts being 100:136 (normal 100:20-35). $21 \gamma / \%$ of monoamino, 2,6-dinitrotoluene, one of the metabolites of TNT, were detected in the patient's urine, proving exposure and absorption.

The patient recovered eventually and left his job and the factory. He was re-examined in 1971 and in July 1973 with no further evidence of increased haemolysis during the nine years which had passed.

\section{Comment}

As already stated, the three cases described have several features in common: job, country of origin, G6 PD deficiency, a negative Coombs test, no previous ingestion of fava beans or mushrooms, and no treatment during the three weeks preceding the haemolytic crisis.
In addition there was the incubation period of two to four days and the almost identical course of the disease, although of different severity (Figure). The delayed start of haemolysis is probably due to the rate of TNT metabolism (Williams, 1959). TNT being insoluble in saline or plasma, one or more of its metabolites are to be blamed for the damage to the red blood cells. According to Dwivedy, Parihar, Sharma, and Verma (1967) 'and Ingham (1941), the bio-transformation of TNT will proceed between 24 and 72 hours after absorption.

It should be further emphasized that the haemolytic crisis following exposure to TNT was the first recorded haemolytic episode in these patients, who had relatively full medical records and adequate medical supervision by their family doctor.

It is interesting that case 3 had been in contact with TNT on a previous occasion without any untoward effect. This can be explained by the very strict preventive measures on the shop floor and the careful attitude of mature workers towards a known hazard when properly instructed.

On the other hand, this case may indicate the importance of the dose-response relationship in developing haemolysis. Unfortunately no simultaneous measurements of the atmospheric level of TNT are available to support this thesis. However, high exposure has been proved on another occasion at different jobs: $1.8 \mathrm{mg} / \mathrm{m}^{3}$ and $2.95 \mathrm{mg} / \mathrm{m}^{3}$, the accepted TLV being $1.5 \mathrm{mg} / \mathrm{m}^{3}$ for a working day of average physical effort.

It is known that all three workers have been employed at the sites of high exposure and that case 3 had passed from a job with a lower degree of exposure at the start of his employment to more polluted areas of the working process a few days before his haemolytic crisis was diagnosed.

In spite of this indication of a possible doseresponse relationship the risk of employing G6 PD deficient individuals in handling TNT cannot be ignored. This may be true for similarly affected 
workers in other chemical industries including drug manufacture (Beutler, 1959, 1968; Dern, Beutler, and Alving, 1955). Thus it is reasonable to consider the investigation of G6 PD activity of red blood cells in the pre-employment examination of certain ethnic groups of TNT workers.

\section{References}

Beutler, E. (1959). The hemolytic effect of primaquine and related compounds: a review. Blood, 14, 103-139. (1968). Clinical aspects of enzymatic deficiencies of erythrocytes and their detection. Triangle, 8, 267272.

Crawford, M. A. D. (1954). Aplastic anaemia due to TNT intoxication. British Medical Journal, 1, 430-437.

Dern, R. J., Beutler, E., and Alving, A. S. (1955). The haemolytic effect of primaquine. Primaquine sensitivity as a manifestation of a multiple drug sensitivity. Journal of Laboratory and Clinical Medicine, 45, 30-39.

Djerassi, L. (1964). Haematuria in TNT exposed workers, unpublished.

Dror, K. (1959). A case of TNT poisoning. Dapim Refuiim, 18, no. $1 / 2$, p. viii.

Dwivedy, A. K., Parihar, D. B., Sharma, S. P., and Verma, K. K. (1967). Charge transfer complexes of 2,4,6 trinitrotoluene and m-dinitrobenzene with some amines. Journal of Chromatography, 29, 120125.

Ermakov, E. V., Aizenshtadt, V. S., and Ventsenostsev, B. B. (1969). Chronic poisoning by trinitrotoluol. Sovietskija Medicina, 32, no. 7, 119-122.

Farrand, N. A. (1961). Personal communication. A modification of Kornberg and Horecker's method for determination of G6 PD activity of red blood cells.

Goodwin, J. W. (1972). Twenty years handling TNT in a shell loading plant. American Industrial Hygienists Association Journal, 33, 41-44.

Hamblin, D. O. (1962). Trinitrotoluene. In Industrial Hygiene and Toxicology, ed. F. A. Patty, Interscience, second edition, Vol. II, pp. 2121-2123, 2153-2154. Interscience, New York and London.

Hassman, P. and Jicha, J. (1967). Activity of blood enzymes with persons working with trinitrotoluol. Sbornik Vedeckych Praci Lekarske Fakulty $K U$ v Hradci Kralove, 10, 505-511.

Hayhoe, F. G. J. (1953). Aplastic anaemia occurring eight years after TNT poisoning. British Medical Journal, 1, 1143-1144.

Hunter, D. (1969). Trinitrotoluene. In The Diseases of Occupations, 4th edition, pp. 546-555. Little Brown, Boston.

Ingham, J. (1941). Improved Webster test for TNT derivative in urine. Lancet, $2,554-555$.

Jope, E. (1946). The disappearance of sulphaemoglobin from the blood of TNT workers in relation to the dynamics of red cell destruction. British Journal of Industrial Medicine, 3, 136-142.

Kaganov, A. L., Fediushina, N. A., and Botchenkova, J. K. (1970). A study of the nervous system under prolonged exposure to trinitrotoluol. Gigiena Truda in Professionalnye Zabolevanjia, 14, no. 1, 47-48.
Kornberg, A. and Horecker, B. L. (1955). Glucose 6 phosphate dehydrogenase. In Methods in Enzymology, Vol. 1, edited by S. P. Colowick and N. O. Kaplan, pp. 323-325. Academic Press, New York.

Maclagan, N. F. (1946). Faecal urobilinogen: clinical evaluation of a simplified method of estimation. British Journal of Experimental Pathology, 27, 190200.

Moeschlin, S. (1964). Trinitrotoluol. In Klinik und Therapie der Vergiftungen, 4th edition, pp. 393-394. Thieme Verlag, Stuttgart.

Oettingen, W. F. von (1941). Trinitrotoluene. In The Aromatic Amino and Nitro Compounds, their Toxicity and Potential Dangers. A Review of the Literature, pp. 111-124. Public Health Bulletin, No. 271. United States Government Printing Office Washington.

Paterson, J. M. (1972). 2-4-6-Trinitrotoluene. In Encyclopedia of Occupational Health and Safety, 1st edition, Vol. II, p. 1436. ILO, Geneva.

Poljak, B. and Pejuskovic, B. (1969). Value of some biochemical analytic methods in workers exposed to TNT. Archiv za Higijena Rada i Toksikologiju, 20, 177-185.

Roberts, H. M. (1941). The TNT health hazard. British Medical Journal, 2, 647-649.

Sievers, R. F. (1947). An evaluation of neurologic symptoms and findings occurring among TNT workers. Public Health Reports, Supplement No. 196, pp. 1-26. United States Government Printing Office, Washington.

Snyder, R. K. and von Oettingen, W. F. (1943). A new test for the detection and the appraisal of exposure to trinitrotoluene. Journal of the American Medical Association, 123, 202-205.

Soboleva, L. P. (1969). The status of the myocardium in chronic trinitrotoluol poisoning. Gigiena Truda $i$ Professionalnye Zabolevanjia, 13, no. 11, 47-48.

Stewart, A., Witts, L. J., Higgins, G., and O'Brien, J. R. P. (1945). Some early effects of exposure to trinitrotoluene. British Journal of Industrial Medicine, 2, 74-82.

Stewart, C. P. and Stolman, A. (1964). In Toxicology, 2nd edition, Vol I, pp. 68-69; Vol. II, pp. 787-789. Academic Press, New York-London,

Szeinberg, A., Adam, A., Myers, F., Sheba, Ch., and Ramot, B. (1959). A hematological survey of industrial workers with lenzyme-deficient erythrocytes. Archives of Industrial Health, 20, 510-516.

Vasilenko, N. M. and Sonkin, I. S. (1969). Mechanism of carbohydrate metabolism disorder in chronic trinitrotoluol poisoning. Gigiena Truda i Professionalnye Zabolevanjia, 13, no. 7, 45-47.

Williams, R. (1959). Trinitrotoluene. In Detoxication Mechanisms, 2nd edition, pp. 411-413, 418-420. Chapman and Hall, London.

Zakharova, A. I. and Manoilova, I. K. (1971). Clinical picture of chronic trinitrotoluene poisoning. Gigiena Truda $i$ Professionalnye Zabolevanjia, 15, no. 12, 28-32.

Received for publication 4 April 1973

Accepted for publication 17 May 1974 